\title{
Philosophy of Islamic Values and Life: A Review of the Methodology of Cultivating Islamic Values Towards Modern Culture
}

\author{
Triyo Supriyatno ${ }^{1} \square$ Cyril Musaddad Abbud El-Aribi ${ }^{2}$, Ahmad Muntakhib ${ }^{3}$ and Mulyani Mudis Taruna ${ }^{4}$ \\ ${ }^{1}$ Dept. Islamic Education, Faculty of Tarbiyah and Teacher Training, UIN Maulana Malik Ibrahim, Malang, Indonesia \\ ${ }^{2}$ English Literature of Translation, Department,Faculty of Social and Political Science, Open University Malang-Indonesia \\ ${ }^{34}$ Religious Research, Development and Training Agency, Ministry of Religious Affairs, Jakarta, Indonesia
}

$\square$ Corresponding Author: Triyo Supriyanto, E-mail: triyo@pai.uin-malang.ac.id

ARTICLE INFO

Received: 08 September 2021

Accepted: 14 October 2021

Published: 18 October 2021

DOI: 10.32996/ijcrs.2021.1.1.1

\section{KEYWORDS}

Philosophy, Islamic values, Islamic life, overview of methodology, civilizing value.

\section{ABSTRACT}

There is no separate discipline of ethics in Islam, and the comparative importance of reason and revelation in determining moral values is open to debate. For most Muslims, what is considered halāl (permitted) and harām (forbidden) in Islam is understood in terms of what God defines as right and good. There are three main kinds of values: (a) akhlāq, which refers to the duties and responsibilities set out in the shari'ah and in Islamic teaching generally; (b) adab, which refers to the manners associated with good breeding; and (c) the qualities of character possessed by a good Muslim, following the example of the Prophet Muhammad. Among the main differences between Islamic and western morality is the emphasis on timeless religious principles, the role of the law in enforcing morality, the different understanding of rights, the rejection of moral autonomy as a goal of moral education, and the stress on reward in the Hereafter as a motivator of moral behavior. An Islamic life system cannot be conveyed only by using verbal suggestions, verbal warnings but also necessary means that can form a complete cultural network. In this regard, intense dialogue with various existing values is needed to bring about a paradigm shift in thinking in the form of symbols that can be applied in local cultural life. The method of cultivating Islamic values demands conditions for improving the quality and performance of Muslim humans who have these values. Islamic values that are properly understood will function as a compass for the direction where and how to live a modern life full of changes in values. Islamic values will still play an important role in the future, especially in providing a moral foundation for the development of science and technology. Religious teachings must be brought closer to the context of modernity.

\section{Introduction}

Since human thought entered a positive and functional stage around the 18th century, religion and Islamic values began to be challenged for their existence. The atmosphere of modern life with massive culture and the fulfillment of various mobility of life technologically and mechanically, on the one hand, has given birth to ethical crisis moral (1). Islam and the change in the estuary that is expected from the dialectical process of Islamic values and modernity is the validity of Islam in the modern era. This is when those efforts are successful. On the other hand, the failure of this process can make religion lose its relevance in modern times.

Value systems, both Islamic and non-Islamic, are the heartbeat of people's lives (2). Values are closely related to the mindset that lives in society so that they are closely related to culture. In this perspective, the values that underlie the movements and activities of individuals in society have something to do with literature, educational patterns, discourses, idioms, holy books, religious books, ancestral wills, and so on are used by the community as a reference for patterns of thinking and acting in everyday life.

Copyright: (c) 2021 the Author(s). This article is an open access article distributed under the terms and conditions of the Creative Commons Attribution (CC-BY) 4.0 license (https://creativecommons.org/licenses/by/4.0/). Published by Al-Kindi Centre for Research and Development, London, United Kingdom. 
That is why the values that live in society cannot stand alone apart from the reality and social reality that surrounds it. The rules and norms of Islamic life cannot be conveyed only by using verbal suggestions, oral warnings, but also necessary means that can form a complete cultural network. In this regard, intense dialogue with various existing values is needed to bring about a paradigm shift of thought in the form of symbols that are applicable to local cultural life.

Islamic values are part of material values that are manifested in the reality of spiritual and physical experiences. Islamic values are levels of personality integrity that reach the moral level (insan kamil). Islamic values are absolute truth, universal, and holy (3). Truth and goodness of religion transcend human ratios, feelings, desires, and passions and are able to transcend the subjectivity of class, race, nation, and social stratification. Islam and the change in the estuary that is expected from the dialectical process of Islamic values and modernity is the validity of Islam in the modern era. This is when those efforts are successful. On the other hand, the failure of this process can make religion lose its relevance in modern times.

If the long dialogical process in the effort to form and cultivate Islamic values is not passed, what will happen is that there is a deep gap between the ideal 'values' and the reality of the existing social reality. If the gulf gets wider, feelings of despair and apathy will soon overtake it with all its consequences that are not beneficial to society itself.

Islamic values are part of material values that are manifested in the reality of spiritual and physical experiences. Islamic values are levels of personality integrity that reach the moral level (insan kamil). Islamic values are absolute truth, universal, and holy (3). Truth and goodness of religion transcend human ratios, feelings, desires, and passions and are able to transcend the subjectivity of class, race, nation, and social stratification. Islam and the change in the estuary that is expected from the dialectical process of Islamic values and modernity is the validity of Islam in the modern era. This is when those efforts are successful. On the other hand, the failure of this process can make religion lose its relevance in modern times.

Islam has a strong potential to answer these challenges. Ernest Gellner, as quoted by Madjid, suggested that among the three monotheistic religions; Judaism, Christianity, and Islam, only Islam is the closest to modernity 'This is because the teachings of Islam on universalism, scripturalism teach that the holy book can be read and understood by anyone, no particular class has monopolized the understanding of the scriptures in the religious hierarchy), teachings about broad community participation (Islam supports participatory democracy), spiritual egalitarianism (there is no priestly-clerical system), and teaches the rational systematization of social life (4). Yusuf Qardhawi assesses the ability of Islam to dialogue in harmony with changes that exist within Islam itself. The potential can be seen from the characteristics of Islam as a religion of rabbaniyah (sourced from God and maintained its authenticity), insaniyah (in accordance with nature and for the benefit of humans), moderate wasthiyyah-taking the middle way), waqiiyah (contextual), clear and harmonious between changes and provisions (5). Islamic Renewal Although Islam has the potential to face change, it is the actuality of this potential that requires the role of its adherent. The inability of Muslims to have an impact on the development of existing potentials. Thus, a long dialogical process is needed in an effort to form an Islamic value culture so that the 'value system' that is coveted (ought) and the reality of social reality that is fry 'runs dynamically.

\section{Literature Review}

\subsection{Philosophy of Islamic Values and Life}

In the context of philosophy, Islamic philosophy rests on divine revelation, namely the Al-Quran and As-Sunnah. According to Hassan Langgulung (6), the foundation of Islamic philosophy is Divinity (Allah), belief in God's people, belief in divine revelation that has been given to the prophets, believe that humans have the potential in the development of morals and spirituality, each of those beliefs the individual is responsible for his actions, belief in life and life after death, and also belief in universals similarities among Muslims.

Axiology is a theory of ethics that is one of the branches of philosophy. From the view of Islam, axiology can be defined as behavior that includes the entire manners in human life. There are three branches within the thought of Islam, and one of them is the thought of morals and manners. This branch includes the matters that should be practiced, which is connected with the manner and moral of humans, such as fair, religiosity, brave, wisdom, and trustworthiness. The venerable characteristic of humans can be seen from the existence of two inclinations, which are the focus towards worldly concerns and the sense of selfishness, and also the conflict between right and wrong. However, both factors can be prevented if humans believe in Allah, by doing His command and avoid from His prohibition. If humans practice the aspects that have been highlighted by the Islamic Philosophy of Education such as make the Prophet Muhammad as the role model in their life, universal peacefulness will be able to be achieved.

Moreover, from the aspect of axiology, a social problem that occurs among teenagers nowadays can be concluded as happen because they are lack knowledge and toward Islamic teaching. Most teenagers do not follow the rule of Islam that makes them lost the purpose of their life. Thus, through the appreciation towards the concept of taqwa as the way of life it is able to help them to distinguish between the pros and cons within their life. This concept stresses the notion of fear of Allah that encourages humans to practice the halal and prevent themselves from the haram. Besides, the ethics of Islam should be entirely implemented including the belief, spiritual, physical, intellectual, emotional, and others. 
Among the characteristic of Islamic manners is; each manner is not opposing the nature of human creation, as its parallel with human's natural tendency. It concerns the human's responsibility in producing the objective person. Furthermore, the purpose of self-perfection is being focused in Islam too, along with the flourished society. It was stated that if moral behaviors' are practiced by the unit of the community; it can produce a quality and excellent society. Regarding the social problems among teenagers, it can be concluded that the problems are not only affecting their life but also include and influence society itself.

\section{Methodology}

This study used a qualitative approach, by emphasizing the analysis of the process of cooperation inference as well as the analysis of the dynamics of the relationship observed phenomena using scientific logic (7). Qualitative research is an approach that produces descriptive data in the form of written words of those who observed that is not poured into terms that are used in qualitative research.

This type of research is the research library (library research). Research Library (library research) is research conducted using the literature (literature) in the form of books, records, and reports the results of previous studies (8). Ideally, professional research using a combination of desk research and field research, or with an emphasis on one of them. But in researching the philosophy of Islamic value and life, and the methodology of cultivating Islamic values towards modern culture, more relevant authors use research methods literature. There are at least three reasons; First, because the issue of the research can only be answered through research libraries, and otherwise impossible to expect data from field research. Second, the literature study is required as one of the stages of its own, which is a preliminary study to better understand the new phenomenon that is growing in the field or in the community. Third, keep reliable reference data to answer the question of research (9).

This study will show the scientific reasoning arguments from the literature review and the results of the researcher's thoughts about an issue or topic of study. This type of research is supported by data obtained from literature sources in the form of research journals, theses, research reports, textbooks, papers, reports seminars, scientific discussions, and so forth. Library materials are discussed critically and in-depth discussions in order to support researching the philosophy of Islamic value and life, and the methodology of cultivating Islamic values towards modern culture.

\section{Results and Discussion}

\subsection{The Methodlogy of Cultivating Islamic Values Towards Modern Culture}

4.1.1 Islamic Value and Modern Life

Every society in its life is always filled with values, rules, and belief systems that are able to shape the thinking and behavior of its members. In social life, usually, a set of values, rules, and beliefs will be transmitted from one generation to generation through a socialization process that eventually forms a tradition in society (10). That is why, as a sociological concept, tradition is usually defined as encompassing a worldview related to values, rules, belief systems, and people's thinking patterns in the whole way of life.

Islamic values are part of material values that are manifested in the reality of spiritual and physical experiences. Islamic values are levels of personality integrity that reach the moral level (insan kamil). Islamic values are absolute truth, universal and holy. Truth and goodness of religion transcend human and human reason, feelings, desires, and passions able to transcend the subjectivity of class, race, nation, and social stratification. Islamic or religious values have two aspects, namely: the "normative aspect" and "the operative side". The normative aspect focuses on considerations of good-bad, right-wrong, right and vanity, blessed or not. Meanwhile, the operative aspect contains five categories which are the principles of standardizing human behavior, namely good bad, half good and neutral, half bad and bad. This is then explained as follows:

1) Wajib (good) Good values done by human beings, obedience will be rewarded with service (reward), and disobedience will be sanctioned.

2) Sunnah (half good) Values that are half good done by human beings, as a refinement of good or obligatory values so that his obedience is rewarded for his services and wickedness without getting sanctions.

3) Mubah (neutral) Values that are neutral, working or not will not be affected by the reward of services or sanctions

4) Makruh (half good) Value that should be left. In addition to the bad, it is also possible for bad habits to occur which will eventually lead to illegality.

5) Haram (bad) Bad value is done because it brings harm and harm to oneself as well as peace in general so that if the subject doing it will get sanctioned, either directly (in this world) or indirectly (in the hereafter) (11).

The five values mentioned above cover all fields, namely concerning the divine values ubudiyah, ilahiyah, muamalah, and human ethical values which consist of social, rational, individual, biophysical, economic, political, and aesthetic values. And of course, bad values are not developed and abandoned. However, the same amount of obligation can still be placed where the obligation is higher than the obligation of others who are lower in the hierarchy. This can be returned to the hierarchy of values according to Noeng Muhadjir, for example, the obligation to worship must be higher than the obligation to perform political, economic, and so on. Besides, each value area can still be specified which are essential and which are instrumental. For example, hijab clothing for people 
women involves two values, namely the essential value, in this case, worship covers the genitals, while the human value (instrumental) is an aesthetic value so that the shape, model, color, way of wearing and so on can vary as long as it covers the genitals.

Because values are ideal and hidden in every human heart, the implementation of these values must be accompanied by an intention. The intention is the intention of someone who does something with full awareness. In this case, this intention is manifested in the actualization of Islamic values. In the process of actualization, Islamic values are manifested in the socialization process in society. In essence, these values are not always recognized by humans. Because values are the foundation and basis for change. Values are a driving force in the life of an individual or group. Therefore, values have an important role in the process of social change.

The role of religion (Islamic values) in the development of society (1) religion as a motivator, religion here is as an encouragement for a person or group to achieve their goals in all aspects of life. (2) religion as a creator and innovator, encourages the spirit to work creatively and productively to build a better world life, and life the hereafter is better too. (3) religion as an integrator, here religion as one that integrates and harmonizes all human activities, both as individuals and as members of society. (4) religion as a sublimator, the meaning of religion is to accuse and sanctify everything human action. (5) Religion as a source of cultural inspiration for the nation, especially Indonesia (12). People's understanding of religion will give birth to attitudes of faith and devotion (Imtaq), while people's mastery of science and technology (Iptek) in the modernization era and industrialization is absolutely necessary. The role of Iman and Taqwa in answering the problems and challenges of modern life: Faith eliminates belief in the power of things, Iman instills a courageous spirit to face death, Iman instills a self-help attitude in life, Iman provides peace of mind. Faith gives life to a person. Faith breeds sincerity and consequences, Faith gives good luck.

Thus, in fact, what is needed in this modern era is none other than mastery of Imtaq and science and technology at the same time so that they become complete human beings. Namely, humans who not only master science and technology but are also able to understand religious teachings as well as implement them in everyday life. The people's mindset and values that are used as guidance are like two surfaces in a coin. The two surfaces are so unified, that any value system, whether Islamic or non-Islamic, will not be able to be internalized into the human soul, without going through intensive intellectual and cultural dialogue with the individuals who carry out the values system.

Thinking patterns are the sediment of a very long cultural process that goes downhill. For this reason, it is not as easy as we imagine to change the established value system. In order to penetrate the real framework of thinking, a serious study of the values that are deeply rooted in society is needed (13). Without this feasibility study, it is likely that a new, more Islamic value-system building will face more obstacles than success. To build a building requires a feasibility study, let alone the desire to disseminate Islamic values. Of course, the process is not as easy as we had hoped. However, it is precisely the feasibility study through the study of religious literature that is normative and historical in nature to obtain new symbols to replace the old ones which Muslims themselves rarely do. We are more accustomed to inculcating Islamic values through pulpits and podiums, majlis taklim, and short lectures that are normative-doctrinal in nature.

To penetrate the twists and turns of modern culture which is very repressive, both in its egotistical, nepotistic, scientific, materialistic, and holistic forms, the value system of the Koran is still actual and inspiring for dialogue with the social pathologies faced by modern humans today. Social pathology that appears in various psychiatric illnesses (stress, heart disease, fatigue, etc.) requires therapy that comes from religious prescriptions that are liberative in nature.

Perhaps, for Muslims themselves, the Islamic values are like that concrete because we have al-Qur'an and al-Hadith as references to these values. Our understanding of the Koran is so perfect that all kinds of social and individual pathologies can be found in the Qur'an. We view the Koran as a finished product that is ready for use in all cases. So at least the impression that we easily get from many sources. If we look at the pathological-deviant patterns of human behavior, we can easily say that these patterns of behavior are not Islamic.

\subsection{Methodology of Cultural Value of Islam}

Community development as a planned social change involves many social elements, including religious adherents, both as subjects and objects. The involvement of these religious believers can be in the planning, implementation, or utilization of development results, whether organized by community institutions and the government or by the community itself. Many studies have been carried out regarding religious teachings in providing encouragement to adherents to participate in a change process.

The bearers of religion, followers, and adherents of religion often come from a variety of different social backgrounds, it is these different social conditions that cause the emergence and spread of ideas and values which in turn can influence human action. Besides, society is not just a part of a structure. social, but also a complex social process, so that the relationship between the values and goals of society is only relatively stable at any given moment. So that this causes in society always changes that move slowly but cumulatively, while some other changes may take place faster, so fast that they may disturb the existing and mature structure. 
The destruction of established social and cultural forms will automatically result in the emergence of new forms which are a continuous process. Thus it is clear that the various groups in society will be affected by these social changes.

The relationship between religion and society presents a fundamental dilemma that can be put forward in three aspects, namely:

a) Religion involves humans in a final situation at which point is born awareness of the highest. Here the question of the supreme meaning and position of man in all plans comes to the fore.

b) Religion concerns sacred things, therefore religion deals with specific understandings and responses that require a sublime view of its object.

c) Religion is based on belief; therefore, its object is supra-empirical (extraordinary) and its teachings cannot be demonstrated or proven empirically (14).

Thus, the esoteric dimension of religion or belief is basically related to other dimensions outside of itself, namely that in addition to being formed by the substance of its teachings, this dimension is also influenced by the social structure in which a belief is manifested by its adherents. So that in certain contexts, on the one hand, religion can adapt and on the other hand it can function as a means of legitimating the process of change that occurs around the lives of its adherents (15).

If we look at the course of history, the Prophet Muhammad SAW himself, in fact, did not immediately aspire to instill the values of Islamic life at once. The method of da'wah of the Prophet is very persuasive, gradual, and humane. When he received the revelation of the Qur'an, instead of directly speaking loudly with loudspeakers in the midst of a society that still has very different values.

The Prophet's preaching was solely limited to his immediate family environment. Then by looking at the local situation and conditions (feasibility study), he just stepped in to disseminate the new values to the surrounding environment. Already taking such a careful method, he had to move to Medina. A sacrifice that we never imagined for this era. And after emigrating he went to Mecca with great courtesy. The old values (Quraish) and their customary leaders were still well supported by the Prophet as before. There was a long dialogue process, not the imposition of a doctrinal value system by the Prophet. In the Koran, it is affirmed by a verse (Al-Quran. Al-Baqarah: 256). The 'uswatun hasanah' dimension of the Prophet was very visible in conveying the new nilal system.

Islamic appearance that is sympathetic, polite, and generous smile is a process that must be followed in the cultivation of Islamic values. The method of cultivating Islamic values through the identification of non-Islamic values in various sermons, mass media, lectures, or social organizations of Islamic society is somewhat less strategic for the meanings of cultivating Islamic values (2).

The methodology of inculcating Islamic values also demands conditions improving the quality and performance of Muslim humans who have these values. The author has the impression that needs further study that we want too much, so it is unrealistic. Meanwhile, the requirements for the fulfillment of our too many desires are still not very well considered. So, it seems that we are less sympathetic in the process of this cultural bargaining. Once again, changing values and thinking patterns is not an easy matter. It requires a feasibility study, a sophisticated method, and a set of tools and other supporting facilities. Not to mention we are talking about the material that is served. Have we ever tested it, with the development of communication science and information security? Muslims need to have a Research and Development Institute to study and reformulate appropriate methods for cultivating Islamic values. The culture of Islamic values runs naturally, traditionally, without being touched by the findings of information and communication technology. If this situation is allowed to continue, the gap between the world of 'ought' (normative doctrines) and 'is' (the real reality that lives in society) will get farther and gradually will make people frustrated quickly. Not only that, maybe we who have been educated since childhood to live a religious life, but in the reality of our daily lives. We live far from the guidance of religion. Religion plays a role in social change by providing ideas and shaping values that influence human action and motivate active processes in community development.

\subsection{Islamic Values and Social Changes}

Everything will change except the change itself (16). Such is the sound of the "law of change" that we have all come to understand. Change is also a universal sunnah that applies universally without being limited by place and time. The change will never stop unless the owner of change (Allah SWT) does. Then, how do Islamic values view a change, more specifically lag in looking at social change ?.

Social change or also called social transformation is a necessity in human life, both individually and collectively (16). This happens because humans naturally have a non-static nature in a condition, they tend to actively respond to a number of events in their surroundings. This response makes human life always dynamic and, in the end, creates a number of new ideas and ideas in order to meet their hopes and needs. With these conditions, the atmosphere of the earth is increasingly full of dynamics. In the course of life on earth, naturally, there will be more and more cultural products (artifacts) that we can encounter from year to year and century to century. It all cannot be separated from the dynamic form of human activity which is a representation of activities by reason and the development of a number of ideas, ideas, and thoughts that humans continue to refine from time to time. This is what clearly 
distinguishes the duties, roles, and functions of humans from other creatures, including if we compare it to, for example, angels, who were created by Allah SWT with static functions, duties, and roles throughout the time of its creation.

The development and advancement of Science and Technology inevitably change the rules and challenges of values that we have considered so far and which we hold firmly. The established values are increasingly being degraded by their dignity by the rapid flow of social change. The negative impact of advances in science and technology is also increasingly seen to accumulate. The accumulated negative impact exists on the human psychological world in the form of stress, heart disease, diabetes, almost all of which are the result of human behavior that is driven by modern life itself. Not to mention the effect on the personal and social order of human life. Physical and nervous exhaustion, boredom and boredom of life, the estrangement of interpersonal and family relationships, lack of warmth between Father-Mother-Son, and so on.

In a situation of social turmoil like that in fact 'religion', especially Islam can make a significant contribution and needs to show its functional strategic role. Religious teachings will always feel actual and functional if we respond to the social pathologies that surround our everyday world today.

Religion that is properly understood will function as a compass for direction in which modern life, which is full of changes in values, will emerge. Islamic values that emphasize justice and egalitarianism will remain true forever. The implication of the existence of science and technology is that the gap between the hove and the hove is widening. If because of the pull of consumerism, people seem to forget about this social reality, but religious advocacy still vocally reminds people not to take the wrong wisdom in this very socially sensitive issue [17).

Islam has established comprehensive human rights. These rights should be exercised and respected in all circumstances. To do so, Islam not only complements it with legal guarantees but also a very effective moral system. Thus, whatever leads to the well-being of the individual or society, in Islam is called good morals, and whatever is detrimental in the so-called bad morals. Islam emphasizes the importance of love for God and love for fellow human beings and opposes formalism. As the following verse of the Qur'an: "Is not the virtue you face towards the East and the West but the virtue is to believe in God, the next day, angels, books, prophets and give the treasure he loves to his relatives, children- orphans, the poor, travelers' (who need help) and people who beg; and (liberate) my servants, establish prayers, and pay zakat; They are the ones who are true in their belief); and they are the ones who are pious "(Qur'an. S. Al-Baqarah: 177)

By placing the pleasure of Allah as the goal of human life, Islam has been equipped with the highest moral standards. This opens unlimited horizons for human moral development in dealing with other human beings. The rules of human relations, then, are not just a matter of propriety or courtesy but are very transcendental in nature. If so, then each human being has the same obligation, that is, both God's creatures have the obligation to serve and worship Him.

In the context of social change, this is very relevant because whatever the agenda for change, whether it is desired to be changed quickly (revolution), slowly (evolution), or halfway between the two (reform) becomes less important, the main thing is that change what is done must be within the frame of Islamic values. This means that the speed of change is not fast too much of a problem from the Islamic perspective. And regarding victims who generally occur in the process of change, if we use an Islamic perspective, the existing changes must be carried out in better (better) ways so that it is almost impossible for changes to be carried out in a radical or violent manner. Even if there are victims, that is an implication of the process that occurs.

\section{Conclusion}

Islamic appearance that is sympathetic, polite, and generous smile is a process that must be followed in the cultivation of Islamic values. The method of cultivating Islamic values through the identification of non-Islamic values in various sermons, mass media, lectures, or social organizations of Islamic society is somewhat less strategic for the meanings of cultivating Islamic values. The methodology of cultivating Islamic values also demands the condition of improving the quality and performance of Muslim people who have these values.

Correctly understood Islamic values will serve as a compass pointing to the direction in which modern life full of changes in these values will take place. Islamic values that emphasize justice and egalitarianism will remain true forever. The role of religion in modern times is very important, even showing symptoms of increasing. The phenomenon of religious awakening, among others, can be observed from the rise of religious activities and the bestselling of religious books. This phenomenon is influenced by several things such as the awareness of the providence of each individual, the failure of modernization and industrialization in realizing a more meaningful life.

Islamic values will still play an important role in the future, especially in providing a moral foundation for the development of science and technology. In this regard, it is necessary to emphasize the importance of harmonizing science and technology (science and technology) with religion (Imtaq). Science and technology must always be based on moral-religious values so as not to be destructive 
to human values (dehumanization). Meanwhile, religious teachings must be brought closer to the context of modernity, so that they can be compatible with all times and places.

Acknowledgement: We sincerely thank everyone who contributed to the discussion of this paper. This research was conducted as part of the development program for a doctoral program of Islamic religious education based on interdisciplinary studies in analyzing the dynamics of Muslim society in understanding values and life in the modern era.

\section{References}

[1] Abdullah, M. A. (1996). Studi agama: normativitas atau historisitas?. Pustaka Pelajar.

[2] Azra, A. (2000). Menuju Masyarakat Madani: Gagasan, Fakta dan Tanggapan.

[3] Azhar, A. T. S. (2018). TITIK TEMU ANTARA ISLAM DAN FILSAFAT. JURNAL YAQZHAN: Analisis Filsafat, Agama dan Kemanusiaan, 4(1).

[4] Basyar, A. B. B. (2020). PENGEMBANGAN E-LEARNING DALAM PERSPEKTIF MAQ? SHID SYAR?'AH. Jurnal Penelitian Ilmiah INTAJ, 4(2), 251274.

[5] BAB, I. A. Penegasan Judul Penelitian ini berjudul "Analisis Penetapan UMK Terhadap Peningkatan Taraf Hidup Buruh Dalam Perspektif Ekonomi Islam"(Studi Pada Kabupaten Lamsel).

[6] Ismail, A. M., \& Jasmi, K. A. (2016). Akidah dan akhlak dalam pendidikan Islam. Penerbit: Universiti Teknologi Malaysia.

[7] Mas' ud, A. (2001). Paradigma Pendidikan Islam. Fakultas Tarbiyah, IAIN Walisongo bekerjasama dengan Pustaka Pelajar, Yogyakarta.

[8] Madjid, N. (1992). Islam: Doktrin dan Peradaban. Jakarta: Yayasan Wakaf Paramadina.

[9] Muksin, M. (2019). ISLAMISASI ILMU PENGETAHUAN DALAM PERSPEKTIF SEJARAH SOSIAL PENDIDIKAN ISLAM. AL-IBRAH, 4(2), $109-128$.

[10] Muhaimin, T., \& Mujib, A. (1994). Dimensi-Dimensi Studi Islam. Surabaya: Karya Abditama.

[11] Purnawan, I. B. (2013). Agama Dan Multikultur: Peran Agama Mewujudkan Multikulturalisme Di Indonesia. Millah: Jurnal Studi Agama, 13(1), $1-22$.

[12] Sahlan, A. (2010). Mewujudkan Budaya Religius di Sekolah: Upaya Mengembangkan PAI dari Teori ke Aksi. UIN-Maliki Press.

[13] Suprayogo, I. (2004). Pendidikan berparadigma al-Qur'an: Pergulatan membangun tradisi dan aksi pendidikan Islam. UIN-Maliki Press.

[14] Zed, M. (2004). Metode peneletian kepustakaan. Yayasan Obor Indonesia. 